\title{
SISTEM EKONOMI \\ (Kajian Komparatif antara Sistem Ekonomi Kapitalis dan Islâm)
}

\author{
Rudy Haryanto \\ (Dosen pada Jurusan Syariah STAIN Pamekasan)
}

\begin{abstract}
Abstrak:
Era globalisasi dan modernisasi menuntut penerapan sistem ekonomi yang kredibel, tidak hanya harus kuat tetapi juga harus menciptakan kemakmuran bagi masyarakatnya. Saat ini, kita tengah mengalami periode anomali. Faham liberalismekapitalisme yang mendasari sistem perekonomian suatu negara dalam bentuk formasi sosial ekonomi kapitalis sangat hegemonik secara global berikut kemakmuran material yang mengiringinya, tetapi berimbas pada terjadinya kontradiksi sosial. Hal ini terjadi karena setiap orang berhak dan bebas bertindak untuk kepentingannya sendiri. Penjual mencari keuntungan sendiri yang sebesar-besarnya dan pembeli mencari kepuasan. Setiap orang dan perusahaan berhak atas kepemilikan mereka sendiri, dan setiap keputusan ditentukan oleh mekanisme pasar. Di sisi lain, Islâm dengan ajaran-ajaranya dalam al-Qur'ân menawarkan konsep sistem ekonomi Islâm yang didasari oleh persaudaraan, persaman, kebebasan, dan keadilan. Dalam sistem ini, semua harta atau kekayaan yang dimiliki manusia merupakan amanah Allâh swt. Dalam harta tersebut ada hak orang lain yang dapat disalurkan dengan mekanisme zakat, infaq, shadaqah, dan dilarang menimbun harta, melainkan harus disalurkan dalam sektor produktif. Walhasil, komparasi ini diharapkan menjadi pijakan para ekonom dalam mengaplikasikan sistem perekonomian yang dapat membebaskan manusia dari aksi penindasan, penekanan, kemiskinan, kemelaratan, dan segala bentuk keterbelakangan.
\end{abstract}

Kata kunci:

Sistem ekonomi, kapilalisme dan ekonomi Islâm 


\section{Pendahuluan}

Di antara sekian banyak permasalahan yang dihadapi dunia saat ini adalah persoalan keterbelakangan atau kemiskinan dan kesenjangan antara si kaya dan si miskin. Kita sebagai anak cucu mewarisi Marxisme, modernisme, dan kapitalisme, yang mengukur segala sesuatunya berdasarkan parameter materialistik. ${ }^{1}$ Lebih dari itu, dapat dikatakan bahwa kita telah dikuasai oleh paham tersebut untuk sedapat mungkin, dengan cara apapun menyamai derajat kemakmuran, kekayaan, dan kemajuan negara maju dan industri. Tidak dapat disangkal bahwa sebagian besar negara-negara yang sedang berkembang, negara miskin dan negara yang terbelakang tersebut adalah mayoritas negara-negara Islâm atau tepatnya negaranegara yang mayoritas berpenduduk Muslim.

Dewasa ini kita mengenal sistem ekonomi² sosialis, sistem terpimpin, kapitalis, campuran dan Islâm. Walaupun sistem perekonomian yang berlainan ditandai oleh lembaga yang juga berlainan, tetapi suatu kumpulan lembaga tidak dapat membentuk suatu sistem perekonomian. Tidak perlu diragukan lagi bahwa sektor kapitalisme telah dikembangkan dengan baik dalam berbagai sudut pandang, dan yang paling jelas adalah dalam sudut pandang perdagangan. Mekkah sendiri yang merupakan tempat agama Islâm lahir telah menjadi pusat perdagangan yang bersifat kapitalis. ${ }^{3}$ Perkembangan perdagangan yang bersifat kapitalis sekarang ini adalah fakta yang tidak asing lagi. Dalam perkembangannya kapitalisme akan mendasari sistem perokonomian suatu negara dalam bentuk formasi sosial ekonomi kapitalis. Tetapi, pada

\footnotetext{
${ }^{1}$ Eko Supriadi, Sosialisme Islâm: Pemikiran Ali Syari'at (Yogyakarta: Pustaka Pelajar, 2003), hlm. vii.

2 Sistem ekonomi yang dimaksudkan di sini adalah sifat bahwa berbagai bagian dan komponen unit, agen, lembaga ekonomi, yang tidak hanya saling berkaitan tapi juga saling mempengaruhi sedemikian rupa dengan suatu tingkat tertentu konsistensi dan keeratan yang pasti. Dengan kata lain, sistem harus merupakan suatu keseluruhan yang berfungsi, walaupun tidak perlu berfungsi dengan sempurna atau menurut kehendak kita. Suatu persyaratan yang sulit bahwsa sistem harus mampu untuk menyesuaikan diri dengan kondisi yang berubah. Uraian lebih jauh tentang hal ini, lihat Gregory Grossman, Sistem-Sistem Ekonomi, terj. Anas Sidik (Jakarta: Bumi Aksara, 2001), hlm. 19

${ }^{3}$ Maxime Rodinson, Islam Dan Kapitalisme, terj. Asep Hikmat (Bandung: IQRA, 1982), hlm. 66.
} 
umumnya formasi sosial ekonomi kapitalis tidak pernah menjadi pedoman perekonomian di negara-negara Islâm pada umumnya, nota bene dipengaruhi oleh adat-istiadat, unsur-unsur moral, dan agama yaitu al-Qur'ân dan al- Hadîts sebagi pijakannya.

Apalagi, saat ini kita memasuki era post-modern, 4 yang antara lain ditandai oleh kecenderungan semakin kuatnya aktifitas yang lebih bernuansa mendekatkan diri kepada Tuhan sekaligus mengamalkan ajaran-ajaran agama yang selama masa modern cenderung ditinggalkan dan posisinya diganti oleh ilmu pengetahuan. Di antara penganut post-modernisme beranggapan bahwa masa modern yang ditandai oleh kehidupan sekuler telah membawa manusia ke arah kehidupan yang semakin materialistik gersang, dan jauh dari nilai-nilai spiritual. Lebih dari itu, kebenaran sesuatu diukur melalui bisa tidaknya sesuatu diuji oleh pancaindera dan jika tidak, maka ia dianggap sebagai khayalan belaka.

Harmoninya perkembangan kemakmuran material, keadilan sosial-ekonomi serta peran agama dan kearifan tradisional, dalam perkembangan awal abad XXI bukan hanya menjadi semacam retorika ilmiah, tapi telah terbukti secara empiris terutama di Asia Timur dan Tenggara. ${ }^{5}$ Hal ini dilandasi oleh nilai demokrasi yang membedakan dengan kebebasan personal sebagai konstruk Asia yang membedakan dengan Barat. Dengan demikian, nilai-nilai kapitalisme dan modernisme bagi Asia telah diserapnya sebagai nilai instrumental, bukan nilai fundamental. Pada saat yang sama tampaknya humanisme-sekular yang menjadi landasan kultural dalam perkembangan kapitalisme di Barat akan digantikan oleh peran Agama dan nilai-nilai tradisional positif yang telah berurat berakar dalam masyarakat Asia.

Ekonomi, seperti diketahui, lebih merupakan bagian dari suatu aspek kebudayaan. Kebudayaan itu tidak lebih dari pada kehidupan di mana kehidupan itu mewujudkan dirinya sendiri dalam seluruh ragam dan kekuatannya. Sejarah peradaban manusia telah manyaksikan timbul dan tenggelamanya banyak sistem. Dalam

4 Pembahasan tentang Post-Modernisme dapat di lihat di Ernest Galner, Post Modernism Religion (London: Rroutledge, 1992), hlm. 47

5 Didin S. Damanhuri, Pilar-Pilar Reformasi Ekonomi Politik: Upaya Memahami Krisis Ekonomi dan Menyongsong Indonesia Baru (Jakarta: CIDES (Pustaka Hidayah), 1999), hlm. 80-81. 
sistem ekonomi terdapat beberapa faham, antara lain kapitalisme, sosialisme, komunisme, Islâm, dan lain-lain, di mana masing-masing tersebut tidak dapat diperbandingkan secara obyektif. 6 Jadi yang dapat dilakukan adalah menunjukkan keunggulan dari setiap sistem ekonomi tersebut di atas sistem lainnya. Untuk itulah tulisan ini mencoba merentang garis besar dari sistem ekonomi kapitalisme dan Islâm.

\section{Kapitalisme dalam Berbagai Perspektif}

Kapitalisme adalah suatu perkataan yang sering dipakai, tetapi jarang diberi batasan. ${ }^{7}$ Istilah kapitalisme telah digunakan dalam dua arti yang berbeda. Lebih tepatnya, kapitalisme telah digunakan dalam berbagai pengertian yang dapat dikelompokan ke dalam dua kelompok istilah atau pengertian semantik, yaitu: ${ }^{8}$ Pertama, kapitalisme digunakan untuk memberikan pengertian tentang sosok atau bangunan perekonomian tertentu. Istilah ini di gunakan untuk anggota masyarakat yang memiliki sifat mentalitas kapitalisnya dengan ciri-ciri pemilikan alat-alat produksi secara pribadi, perusahan-perusahaan bebas, berusaha mencari keuntungan merupakan pendorong utama dalam aktifitas perekonomian, produksi untuk pemasaran, penghematan uang, mekanisme persaingan, rasionalisasai dalam pengelolalaan perusahaan dan lainlain. Kedua, kapitalisme merupakan istilah yang diberikan kepada suatu masyarakat, secara keseluruhan, yang susunan masyarakat dan mentalitas kapitalisnya menonjol atau sangat menonjol sebagi contoh masyarakat Eropa Barat dan Amerika.

Kapitalisme berasal dari istilah capaital (capitale, berasal dari bahasa latin caput, yang berarti kepala), yang artinya dana, sejumlah

${ }^{6}$ Obyektif yang dimaksud di sini adalah suatu penilaian secara logis harus diterima oleh para pendukung dari semua sistem ekonomi. Lihat M. Abdul Mannan, Teori dan Praktek Ekonomi Islam, terj. M. Nastangin (Yogyakarta: Dana Bhakti Prima Yasa, 1997), hlm. 312.

${ }^{7}$ Kapitalisme merupakan ideologi, dalam arti sekumpulan ide yang dianut oleh suatu kelompok sosial dan merupakan gambaran kenyataan sosial tertentu serta membentuk nilai-nilai dan sasaran yang ingin dicapai atau dipelihara. Ideologi tumbuh dalam suatu sejarah tertentu sebagai reaksi terhadap keadaan dan kebutuhan tertentu dalam hubungan dengan sekumpulan ide yang lain. Lebih lanjut baca Grossman, Sistem-sistem, hlm. 45.

8 Supriadi, Sosialisme Islam, hlm. 28. 
uang, dan bunga uang pinjaman. Dalam perspektif lain, istilah kapital berarti kekayaan uang suatu perusahaan. ${ }^{9}$ Jadi, kapitalisme dapat dimaknai sebagai suatu sistem ekonomi di mana kekayaan produktif terutama di miliki secara pribadi dan produksi terutama dilakukan untuk penjualan. ${ }^{10}$ Tujuan pemilikan pribadi adalah untuk mendapatkan suatu keuntungan yang tinggi dari penggunaan kekayaan produktif, dan hal ini merupakan pendorong ekonomi yang besar dalam sejarah sampai saat ini.

Dalam sistem ekonomi kapitalis, menurut Fathonah Business Consulting ( $F B C)$, setiap orang berhak dan bebas bertindak untuk kepentingannya sendiri. Penjual mencari keuntungan sendiri. Penjual mencari keuntungan yang sebesar-besarnya. Pembeli mencari kepuasan, setiap orang dan perusahaan berhak atas kepemilikan mereka sendiri, dan setiap keputusan ditentukan oleh mekanisme pasar, serta fungsi pemerintah hanya melindungi kepentingan pribadi dan menjamin mekanisme pasar terjadi secara fair. ${ }^{11}$ Karenanya, menurut Kwik Kian Gie, sebagaimana dikutip oleh Damanhuri, kapitalisme merupakan faham yang membolehkan orang per orang (individu) memiliki modal dan dibolehkannya modal itu digelembungkan terus sampai tanpa batas besarnya, melalui usaha, yaitu ikut sertanya dalam proses produksi dan distribusi, atau dibungakan dalam bank dan dispekulasikanya di bursa efek. ${ }^{12}$ Konsekwensi positif negatif pemikiran ini dalam mengkonstruksi masyarakat modern masih menjadi ajang kontroversi terutama bagi

\footnotetext{
9 Penjelasan secara panjang lebar baca Beta Perkasa, "IMF, Bank Dunia dan Evolusi Kapitalisme," dalam Jurnal Pangsa-FE UGM, edisi 6, VI, (Mei 2001), hlm. 138. Kata "kapitalis" barangkali muncul pada abad ketujuh belas, guna menyebut kata pemilik capital. Anehnya, istilah kapitalisme merupakan yang paling baru. Adam Smith yang biasanya dianggap sebagai ahli teori kalsik kapitalisme tidak menggunakan istilah itu sama sekali. Dia melukiskan apa yang dianggapnya sebagai sistem dasar kebebasan. Istilah ini baru menjadi umum setelah diterbitkan karya utama Sombart, dan umumnya dianggap sebagai lawan sosialisme.

10 Grossman, Sistem-sistem, hlm. 47

11 Fathonah Business Consulting (FBC), Sistem Ekonomi Islam, makalah disajikan dalam Seminar dan Lokakarya Membangun Ekonomi Syariah di Madura, Lembaga Pengkajian dan Penerapan Syariat Islam (LP2SI) Kabupaten Pamekasan (Pamekasan: 7 Januari 2008), hlm. 17.

12 Damanhuri, Pilar-pilar Reformasi, hlm. 78.
} 
negara-negara di mana peran agama dan nilai tradisional yang positif sangat penting.

Jika digali secara teoritik, pandangan kapitalisme pada dasarnya bersumber dan berakar pada pandangan filsafat ekonomi klasik, terutama ajaran Adam Smith yang dituangkan dalam karyanya Wealth of Nation (1776). Selain Adam Smith, yang umumnya disebut sebagai tokoh perintis pandangan ekonomi klasik adalah dua pemikir ekonomi lainnya, yakni David Ricardo dan James Mill. Namun banyak penulis memasukkan juga pengikut dan pemikir lainnya ke dalam ekonomi klasik seperti, Jeremy Bentham, Thomas Robert Malthus, atau J.B.Say. ${ }^{13}$

Dunia sejarah ilmu ekonomi semakin sempurna kerena munculnya berbagai pemikiran mengenai ekonomi dan keuangan yang baru dari pemikiran John Maynard Keynes (1883-1946), yang dinilai oleh para ahli ekonomi sebagai ekonomi modern. Lebih dari itu, dengan munculnya buku hasil pikirannya The General Theory, ternyata dinilai banyak ahli ekonomi dunia sebagai suatu revolusi dalam pemikiran ekonomi. Ia benar-benar tokoh pemikir ekonomi yang banyak mempengaruhi filsafat sistem ekonomi dan menjadi "arsitek kapitalisme yang tahan hidup". ${ }^{14}$

Keseluruhan filsafat pemikiran penganut ekonomi klasik tersebut dibangun di atas landasan filsafat ekonomi liberalisme. Mereka pecaya pada kebebasan individual (personal liberty), pemilikan pribadi (private property), dan insiatif individual serta usaha swasta (private enterprise). Kepercayaan dan pandangan ini disebut liberal dibandingkan dengan pandangan lain waktu itu yakni merkantilisme, yang membatasi perdagangan dan industri. Dengan kata lain, fondasi filosofi ekonomi kapitalis menganggap manusia sebagai makhluk individualis (invisible hand). Kepentingan masyarakat terpenuhi. Dasar pijakannya adalah kebebasan individu dalam kepemilikan alat produksi. Mereka saling berkompetensi di pasar sehingga paradigma sistem ekonomi kapitalisme adalah ekonomi pasar. ${ }^{15}$

13 Baca Mansour Fakih, Sesat Pikir Teori Pembangunan dan Globalisasi (Yogyakarta: Insist Press dan Pustaka Pelajar, 2001), hlm. 45-46.

14 Bachrawi Sanusi, Tokoh Pemikir dalam Mazhab Ekonomi (Jakarta: Rineka Cipta, 2004), hlm. 105-106.

${ }_{15}$ M. Husein Sawit, "Sistem Ekonomi Islam", dalam Metodologi Ilmu Ekonomi Islam: Suatu Pengantar, ed. Gunawan Mohammad (Yogjakarta: UII Press, 1999), hlm. viii. 
Dengan penjelasan yang lebih gamblang, Umer Chapra mengatakan bahwa kapitalisme memiliki lima ciri utama, yaitu: (1) Ia menganggap ekspansi kekayaan yang dipercepat, produksi maksimum dan pemuasan "keinginan" sesuai dengan preferensi individu sebagai sesuatu yang sangat penting untuk kesejahteraan manusia; (2) Ia menganggap kebebasan individu tanpa batas untuk mencari kekayaan pribadi dan untuk memiliki dan mengatur kepemilikan pribadi (private property) sebagai sebuah keharusan bagi inisiatif individu; (3) Ia mengasumsikan inisiatif individu bersama dengan pengambilan keputusan yang terdesentralisasi dalam operasi pasar bebas sebagai syarat yang mencukupi untuk mewujudkan efisiensi optimum pengalokasian sumber daya; (4) Ia tidak mengakui perlunya peranan pemerintah atau pertimbangan nilai kolektif baik dalam efisiensi alokasi maupun keadilan distribusi; dan (5) Ia mengklaim bahwa pemenuhan kepentingan pribadi oleh semua individu juga akan secara otomatis memenuhi kepentingan sosial bersama. ${ }^{16}$

\section{Evolusi Kapitalisme}

Kapitalisme merupakan suatu fonomena historis. ${ }^{17}$ Ini mengisyaratkan bahwa kapitalisme tumbuh melalui suatu periode waktu yang panjang karena itu para sejarah akan berbeda pendapat mengenai kapan fenomena tersebut secara logis dikatakan ada. Pada masa permulaannya kapitalisme, segi semangat yang sering mendapatkan penekanan adalah semangat usaha, berani mengambil resiko, persaingan dan keinginan untuk mengadakan inovasi. Tata nilai yang memadai kapitalisme adalah individualisme, kemajuan material, dan kebebasan politik. ${ }^{18}$

Kapitalisme klasik yang dirumuskan oleh Adam Smith lebih memiliki spektrum spesifik, yaitu peran negara yang minimal, suatu utopia libertarian dengan slogan laissez-faire. ${ }^{19}$ Dalam pandangan

\footnotetext{
16 Umer Chapra, Islam dan Tantangan Ekonomi, terj. Nurhadi Ihsan dan Rifqi Amar, (Surabaya: Risalah Gusti, 1999), hlm. 18.

17 Peter L. Beger, "Kapitalisme Suatu Fenomena", dalam Arus Pemikiran Ekonomi Politik: Esei-Esei Terpilih, ed, Amir Effendi (Yogyakarta: Tiara Wacana, 1999), hlm. 282. 18 Grossman, Sistem-sistem, hlm. 48.

19 Slogan ini berarti tidak ada campur tangan pemerintah dalam kegiatan ekonomi, alam semesta saja dapat mengatur dirinya sendiri. Periksa Ibid.
} 
Smith, perilaku manusia secara alamiah didorong oleh enam pertimbangan motivasi kepentingan dirinya sendiri, hasrat untuk berkelakuan secara bebas kecenderungan untuk bersikap sopan santun, kebiasaan untuk bekerja dalam dunia modern untuk mengangkut barang dan menukarnya dengan barang lain melalui transaksi jual beli. Berdasarkan serangkai pertimbangan di atas, teori mazhab klasik menegaskan bahwa kebutuhan manusia akan terpenuhi dengan cara yang paling baik jika kebebasan dan kemandirian individu dijamin dalam kehidupan masyarakat. Oleh sebab itu, persaingan yang bebas merupakan hal yang lumrah dan akan mengembangkan kreatifitas individu dalam berusaha.

Memang benturan kepentingan antara individu tidak bisa dihindari, namun secara bersamaan keadaan tersebut seakan-akan diarahkan oleh tangan pengendali yang tidak kentara (invisible hand) yang selanjutnya akan mencapai titik keseimbangan (equilibrium) dan secara menyeluruh masyarakat berkembang ke arah kemajuan dan kesejahteraan. Pemikiran ini sangat menghegemoni dalam perekonomian Inggris pada abad XVIII dan XIX M. Negara tidak melakukan intervensi terhadap perekonomian, dan membiarkan pasar beraktifitas dengan bebas dan otonom. Kegiatan perekonomian benar-benar diatur pasar, persaingan antara pemasok dan pembeli barang dan jasa amat dominan. Kondisi inilah yang disinyalir Marxisme sebagai adanya konsentrasi modal. Para kapitalis yang bermodal kecil akan kalah dalam bekompetisi karena tidak bisa menekan biaya produksi sehingga barang yang dijual ke pasar mahal. Mereka akan tersisih, selanjutnya laba yang besar selalu diperoleh para kapitalis besar. Gurita kapitalis raksasa semakin kuat mencengkeram pasar, sedangkan buruh semakin lemah bargaining power-nya terhadap majikan. Inilah yang selanjutnya menghasilkan kapitalisme industrial yang terpecah (fragmented). Pertumbuhan tinggi (booms) memang tercapai tetapi menghasilkan kesengsaraan yang meluas.

Pusat pusaran kapitalisme bergeser dari Eropa pada abad XVIII dan ke arah Amerika pada abad XX. Salah seorang monetaris dari negara Paman Sam, Milton Friedman, mengidentifikasi paling tidak setelah tahun 1930 wacana liberalisme di Amerika berbeda dengan wacana serupa yang berkembang di daratan Eropa. Pergeseran tersebut dapat dilihat dari dua hal, yaitu: (1) Tujuan 
puncak (ultimate goal) liberalisme Amerika bukan kebebasan individu, seperti anggapan yang terbentuk selama ini, tetapi kesejahteraan (welfare) dan pemerataan (equality); (2) Dalam perspektif liberalisme Amerika, individu bukan lagi menjadi entitas paling puncak (ultimate entity) sehingga intervensi negara lebih dipercaya dari pada kebebasan individu. ${ }^{20}$

Setelah Perang Dunia II, di Amerika masalah pengangguran yang disebabkan oleh pasar bebas memaksa pemerintah melalui The Employment Act 1941, guna menjamin penggunaan sumberdaya untuk mencapai kesempatan kerja penuh (full employment) pada saat yang sama menjaga kestabilan harga. Krisis yang sebelumnya amat rentan terhadap terjadinya evolusi sosial dapat dicegah oleh turut campurnya negara untuk mengatasi depresi ekonomi.

\section{Kritik Untuk Kapitalisme}

Pergeseran kapitalisme secara posisi pusat maupun asumsi yang menyertainya pada abad 20, juga dapat ditinjau dalam hal pembuatan kebijakan ekonomi. Liberalisme abad XX cenderung mengambil keputusan secara terpusat (centralized), sedangkan liberalisme ekonomi abad XIX lebih cenderung tersebar (decentralized).

Amin Rais memberikan kritik terhadap kapitalisme, yaitu : Pertama, kapitalisme melahirkan ketidaksamaan atau kesenjangan ekonomi dalam masyarakat. Kedua, kapitalisme secara teoritis memberikan kesempatan sama kepada setiap anggota masyarakat, dalam kenyataannya bersifat diskriminatif. Ketiga, semboyan kapitalisme yang berupa "berproduksi untuk dapat berproduksi lebih besar" menyebabkan keserakahan dan berkembangnya kehidupan yang materialistik. ${ }^{21}$

George Soros melihat bahwa kegagalan sistem kapitalisme diakibatkan oleh laissez-faire, yang ia sebut dengan istilah fundamentalisme pasar. ${ }^{22}$ Fundamentalisme pasarlah yang membuat

\footnotetext{
20 Sutrisno, Welfare State dan Welfare Society dalam Ekonomi Pancasila (Yogyakarta: FEUGM, 1982), hlm. 2.

21 Nursalim, Ekonomi Islam Sistem Ekonomi Alternatif, makalah disajikan dalam Seminar Ilmiah Keislaman FE Unair Surabaya (Surabaya: FE UNAIR, 20 Mei 1995). hlm. 3

22 George Soros, Krisis Kapitalisme Global, terj. Dindin Solahudin, (Yogyakarta: AlQalam, 2001), hlm. 2.
} 
sistem kapitalisme global tidak sehat dan tidak kokoh. Pada akhir Perang Dunia II, pergerakan modal internasional dibatasi, dan lembaga-lembaga Bretton Woods didirikan untuk menfasilitasi perdagangan saat tidak ada pergerakan modal. Batasan-batasan itu dicabut dan barulah ketika Margareth Thatcher dan Ronald Reagen berkuasa sekitar 1980, fundamentalisme pasar terjadi ideologi dominan yaitu fundamentalisme pasar yang membuat modal berkuasa penuh.

Soros sendiri tidak ingin membuang kapitalisme, meskipun memiliki sejumlah kekurangan, ia lebih baik ketimbang alternatifalternatif lain. Alih-alih membuang Soros ingin mencegah sistem kapitalisme global dari kemungkinan merusak dirinya sendiri. Untuk tujuan ini, kita sangat membutuhkan konsep masyarakat terbuka. Ide masyarakat terbuka (open society) Soros dipengaruhi oleh Karl Popper, seorang ahli filsafat ilmu, yang bukunya Open Society and Its Enemies berpengaruh terhadap Nazi dan rezim-rezim komunis yang dialami Soros. Rezim-rezim itu memiliki kesamaan, yaitu mereka mengklaim kebenaran mutlak dan memaksakan pandangan-pandangan mereka kepada dunia dengan menggunakan kekerasan. Popper mengajukan bentuk organisasi sosial yang berbeda, organisasi sosial yang menyadari bahwa tak seorangpun dapat mencapai kebenaran mutlak. Pemahaman kita mengenai dunia tempat kita hidup bersifat tidak sempurna dan masyarakat sempurna tak mungkin dapat diwujudkan.

Kritik Soros atas sistem kapitalisme global dapat dipilih menjadi dua. Pertama, kritik yang berkaitan dengan kerusakan pada mekanisme pasar. Di sini Soros berbicara megenai instabilitas yang menggoncang pasar uang. Kedua, kritik yang berkaitan dengan kekurangan-kekurangan, yang ia sebut sebagai sektor non-pasar. Ini terutama diakibatkan karena kegagalan politik dan erosi nilai-nilai moral baik pada tingkat nasional maupun internasional. Namun masyarakat terbuka yang digagasnya pun tidak lepas dari ancaman dari arah berlawanan yaitu kekurangan kohesi sosial dan ketiadaan pemerintah. 23

\footnotetext{
${ }^{23}$ Ibid.
} 


\section{Ekonomi Islâm}

Setelah PD II, gejala menarik yang terdapat di negara-negara Islâm yang penduduknya mayoritas beragama Islâm adalah bahwa di negara-negara ini terlihat kecenderungan untuk melihat ke dalam dirinya sendiri dan kembali ke identitasnya. Para ekonom kontemporer mulai mencari lagi sampai mereka menyadari kembali betapa pentingnya kajian ekonomi yang berkarakter religius, bermoral, dan humanis. Pendekatan ini membuat mereka tidak memfokuskan perhatian hanya pada variabel-variabel ekonomi semata. Para cendekiawan ini menganggap kesejahteraan umat manusia merupakan hasil akhir dari interaksi panjang sejumlah faktor ekonomi dan faktor-faktor lain, seperti moral, sosial, demografi, dan politik. ${ }^{24}$

Seluruh paradigma berfikir di bidang ekonomi serta aplikasinya dalam kehidupan sehari-hari disesuaikan dengan ajaran Islâm sesuai dengan nilai-nilai Qur'ânî, yakni persaudaraan, persamaan, kebebasan, dan keadilan. ${ }^{25}$ Dalam hal ini, ilmu ekonomi yang lebih terandalkan dalam menjaga keselamatan seluruh manusia dan alam semesta, yakni ekonomi yang memiliki nilai-nilai kebenaran (logis), kebaikan (etis), dan keindahan (estetis). Ekonomi yang dapat membebaskan manusia dari aksi penindasan, penekanan, kemiskinan, kemelaratan, dan segala bentuk keterbelakangan.

Kriteria ekonomi tersebut ada pada sistem ekonomi Islâm. Lebih lanjut, Sistem ekonomi Islâm, menurut Fathonah Business Consulting $(F B C)$, berarti bahwa semua harta atau kekayaan yang dimiliki manusia adalah amanah Allâh swt, dalam harta tersebut ada hak orang lain yang dapat disalurkan dengan mekanisme zakat, infaq, shadaqah, dan dilarang menimbun-nimbun harta, melainkan harus disalurkan dalam sektor produktif, serta pelarangan riba. ${ }^{26}$

Berbagai praktek dan kebijakan ekonomi yang berlangsung pada masa Rasûlullâh saw dan al-khulafấal-rasyidûn merupakan contoh empiris yang dijadikan pijakan bagi bagi para cendekiawan muslim dalam melahirkan teori-teori ekonominya. Satu hal yang jelas,

${ }^{24}$ Adiwarman Azwar Karim, Sejarah Pemikiran Ekonomi Islam (Jakarta: Raja Grafindo Persada, 2006), hlm. vii.

25 Ibid. hlm. 27.

${ }^{26}$ Fathonah Business Consulting (FBC), Sistem Ekonomi, hlm. 18. 
fokus perhatian mereka tertuju pada pemenuhan kebutuhan, keadilan, efisiensi, pertumbuhan, dan kebebasan yang tidak lain merupakan objek utama yang mengispirasi pemikiran ekonomi Islâm sejak masa awal. ${ }^{27}$

\section{Nilai Dasar dan Prinsip Ekonomi Islâm}

Secara terminologi, sistem ekonomi Islâm dapat diartikan sebagai sebuah sistem ekonomi yang terjadi setelah prinsip ekonomi yang mejadi program kerjanya, dipengaruhi atau dibatasi oleh ajaranajaran Islâm. Fondasi filosofinya adalah manusia dianggap sebagai hamba Allah yang semua perbuatan di dunia akan dipertanggungjawabkan di kemudian hari, yang dasarnya adalah iman. Oleh karena itu, perilaku yang diutamakan oleh individu yang beriman adalah kerjasama bukan kompetisi. Demikian juga, walaupun diperbolehkan menguasai alat produksi secara individu dan ada kebebasan dalam berusaha, mereka akan memperhatikan keseimbangan antara kepentingan individu dan kepentingan masyarakat. Karenanya, paradigmanya adalah syarî'ah, dan hal ini menjadi dasar dalam sistem ekonomi Islâm.

Asas pokok filsafat ekonomi Islâm didasarkan atas pemahaman bahwa: (1) Semua yang ada (alam semesta), bahkan harta kekayaan yang dikuasai oleh manusia adalah milik Allah;28 (2) Allah itu Esa, Pencipta segala makhluk, dan semua yang diciptakan tunduk kepada-Nya. Seluruh manusia berasal dari subtansi yang sama. Semua manusia sama, tidak berkelas-kelas;29 (3) Iman kepada hari Akhir, ini diperlukan karena mempengaruhi tingkah laku ekonomi manusia. ${ }^{30}$

Dari ketiga asas pokok filsafat ekonomi Islâm ini melahirkan nilai-nilai dasar ekonomi Islâm. Karenanya, teori ekonomi Islâm dilandasi atas dasar tawhîd (keimanan), 'adl (keadilan), nubuwwah (kenabian), khilâfah (pemerintahan), dan ma'ad (hasil). Dari dasar tersebut, kemudian, dibangunlah tiga prinsip derivatif yang menjadi ciri dan cikal bakal sistem ekonomi Islâm, yaitu: (1) Multiple ownership (kepemilikan multijenis), yakni sistem ekonomi Islâm mengakui

${ }^{27}$ Karim, Sejarah, hlm. 10.

28 Al-Qur'ân Surat al-Baqarah (2): 6

${ }^{29}$ Lihat Al-Qur'ân Surat Al-Mu'min (40): 13

30 Ibid., al-Zalzalah (99): 1-8 
bermacam-macam bentuk kepemilikan, baik oleh swasta, negara atau campuran; (2) freedom to act (kebebasan bertindak/berusaha), dalam arti bahwa freedom to act bagi setiap individu akan menciptakan mekanisme pasar dalam perekonomian; 3) social justice (keadilan sosial), yakni bahwa dalam sistem ekonomi Islâm, pemerintah bertanggung jawab menjamin pemenuhan kebutuhan dasar rakyatnya dan menciptakan keseimbangan sosial antara yang kaya dan yang miskin. ${ }^{31}$

Di atas semua nilai dan prinsip yang telah diuraikan di atas, dibangunlah konsep yang memayungi kesemuanya, yakni konsep akhlak. Akhlak inilah yang menjadi panduan para pelaku ekonomi dan bisnis dalam melakukan aktivitasnya. ${ }^{32}$ Kebebasan yang tak terbatas dan mengakibatkan pertentangan antara yang kuat dan kaya dengan lemah dan miskin selanjutnya akan menghancurkan tatanan sosial. ${ }^{33}$ Keadilan dalam produksi dan konsumsi (ekonomi) adalah aransemen efisien dan memberantas pemborosan. Bahkan menurut Edi Swasono, dalam Islâm keadilan adalah titik tolak dan sekaligus proses dan tujuan semua tindakan manusia. ${ }^{34}$

Al-Qur'ân yang merupakan sumber utama ajaran Islâm telah menetapkan berbagai aturan sebagai hidâyah bagi umat manusia dalam melakukan aktivitas di setiap aspek kehidupanya, termasuk bidang ekonomi. Prinsip Islâm yang paling mendasar adalah kekuatan tertinggi hanya milik Allah semata dan manusia diciptakan sebagai khalîfah-Nya di muka bumi. ${ }^{35}$ Beberapa prinsip pokok tentang kebijakan ekonomi Islâm adalah: (1) Allah swt. adalah penguasa tertinggi sekaligus pemilik absolut seluruh alam semesta; (2) manusia hanyalah khalîfah Allah swt. di muka bumi, bukan pemilik yang sebenarnya; (3) semua yang dimiliki dan didapatkan manusia adalah

31 Lebih lanjut baca Adiwarman A. Karim, Ekonomi Mikro Islami (Jakarta: Raja Grafindo Persada, 2007), hlm. 42-44.

32 Ibid., hlm. 34

33 A.M. Saifuddin, "Filsafat, Nilai Dasar, Nilai Instrumental, dan Fungsionalisasi Konsep Ekonomi Islam”, dalam Solusi Islam atas Berbagai Persoalan Umat, ed. Tim GIP (Jakarta: Gema Insani Pess, 1998), hlm. 39-45.

34 Sri Edi Swasono, Pandangan Islam dalam Sistem Ekonomi Indonesia (Jakarta: UI Press, 1987), hlm. 11.

35 Lihat antara lain al-Qur'ân Surat Al-Imran (3): 26, al-Hjjr (15): 2, al-Mulk (67): 1, alBaqarah (2): 30, al-Nisâ (4): 166, dan al-Fâthir (35): 39 
atas rahmat Allah swt.; (4) kekayaan harus berputar dan tidak boleh ditimbun; (5) ekploitasi ekonomi dalam segala bentuknya, termasuk ribâ, harus dihilangkan; (6) menetapkan sistem warisan sebagai media redistribusi kekayaan yang dapat mengeliminasi berbagai konflik individu; (7) menetapkan berbagai bentuk sedekah, baik yang bersifat wajib maupun sukarela, terhadap para individu yang memiliki harta kekayaan yang banyak untuk membantu para anggota amsyarakat yang tidak mampu. ${ }^{36}$

Namun demikian, seperti halnya faham kapitalisme yang banyak menjadi sasaran kritik, teori ekonomi Islâm pun tidak lepas dari kritik. Dari berbagai kritik itu dapat diklasifikasikan ke dalam tiga kelompok, yaitu: Pertama, the adjusted capitalism school, yang mengatakan bahwa ekonomi Islâm merupakan penyesuaian sistem kapitalis apabila dihilangkan yang haram dan ribâ, seperti alkohol, perjudian, bunga bank, dan sebagainya. Kedua, kelompok konvensional, yang tidak menginginkan adanya perubahan dalam sistem ekonomi, karena mereka menganggap sistem tersebut telah berjalan atau dipraktikkan sejak lama dan mereka lebih senang mengembangkan teori ekonomi yang ada daripada menginvestasikan waktunya untuk mendalami teori ekonomi Islâm. Ketiga, the sectarian diversity school, yang mengatakan bahwa dalam Islâm banyak sekte sehingga tidak memungkinkan menarik suatu benang merah untuk pengembangan ekonomi Islâm. Mereka mengatakan setiap sekte membangun caranya sendiri sehingga telah membingungkan banyak ahli. $^{37}$

\section{Sistem Ekonomi Kapitalis dan Islâm: Suatu Kajian Komparatif}

Jika dilihat dari tujuan dan prinsip ekonomi, memang tidak ada perbedaan antara sistem ekonomi Islâm dengan sistem ekonomi lain, ${ }^{38}$ sebab semua sistem ekonomi, termasuk sistem ekonomi Islâm, bekerja berdasarkan: Pertama, tujuan yang sama yaitu mencari pemuasan berbagai keperluan hidup manusia, baik keperluan hidup itu bersifat pribadi maupun masyarakat secara umum. Kedua, motif ekonomi yang sama, yaitu setiap orang atau masyarakat akan

\footnotetext{
${ }^{36}$ Karim, Sejarah, hlm. 36.

37 Ibid., hlm. 39.

38 Muhammad Daud Ali, Sistem Ekonomi Islam: Zakat dan Wakaf (Jakarta: UI Press, 1988), hlm. 17.
} 
berusaha mencapai hasil yang sebesar-besarnya dengan tenaga atau ongkos yang sekecil-kecilnya dalam waktu yang sesingkatnya. Namun dilihat dari perbedaan hidup manusia yang harus dipenuhi dengan kegiatan ekonomi itu dan batasan-batasan yang ada, karena falsafah atau pandangan hidup serta agama, maka terdapat perbedaan dalam pelaksanaan tujuan.

Baik Orientalis maupun ilmuan sosial menduga bahwa Islâm tidak selaras dengan kapitalisme, tetapi secara tipikal penjelasan mereka menyimpang, menjadi analisis teologi versus kelembagaan. Para Orientalis cenderung memandang Islâm secara inheren sebagai kontradiktif dengan kapitalisme sebagai akibat adanya doktrindoktrin dasar yang tidak dapat diubah.

Kapitalisme memandang manusia sebagai individu, sehingga dibiarkan bersaing bebas sebebas-bebasnya. Akibatnya banyak orang yang memang sejak lahir sebagai proletariat selamanya tetap menjadi proletariat karena tidak mampu bersaing dengan majikan atau owner. Tetapi, Islâm memandang manusia sebagai satu kesatuan, sehingga Islâm menganjurkan agar manusia selalu mengingat yang lain, khususnya yang mampu terhadap yang kurang mampu.

Paham kapitalisme menganggap harta adalah hak milik manusia, karena manusia yang mengusahakannya, dan oleh karenanya, manusia bebas mendapatkan dan bebas pula memanfaatkannya. Sedangkan Islâm, memiliki pandangan yang khas tentang harta. Bahwa harta pada hakekatnya adalah milik Allah. ${ }^{39}$ Dan, harta yang dimiliki manusia sesungguhnya merupakan pemberian dari Allah yang dikuasakan kepada manusia. Kata rizki sendiri artinya memang pemberian. ${ }^{40}$ Oleh karenanya, harta mestinya hanya boleh dimiliki dan dimanfaatkan sesuai dengan kehendak Allah.

Para ilmuan sosial memusatkan perhatian pada ketegangan situasional dan mungkin temporer antara Islâm dan kapitalisme. Mereka mengaitkan ketegangan ini dengan struktur dan kondisi historis tertentu seperti feodalisme, sultanisme, imperialisme, dan lain

\footnotetext{
39 Lihat al-Qur'ân Surat al-Nûr (24): 33
}

40 Lihat al-Qur'ân Surat al- $\underline{\text { Hadîd (57): } 7}$ 
lain. Dibandingkan dengan orientalis, ilmuwan sosial lebih memandang konflik antara agama dan ekonomi sebagai persial, bukan serba meliputi.

Kita telah melihat bahwa selalu saja terdapat sektor-sektor kapitalistik di negara-negara Islâm, dan mungkin sektor ini pada periode-periode tertentu sangat luas. Hal ini disebabkan oleh adanya sistem perekonomian kapitalis, yaitu suatu sistem di mana sektor kapitalis mempunyai peranan yang dominan, yang mempengaruhi sektor-sektor lain tanpa ia sendiri banyak terpengaruh oleh sektorsektor tersebut, termasuk di dunia Islâm.

\section{Kesimpulan}

Walaupun sistem perekonomian yang berlainan ditandai oleh lembaga yang juga berlainan, tetapi suatu kumpulan lembaga tidak dapat membentuk suatu sistem perekonomian. Salah satu cara untuk membedakan sistem perekonomian adalah menurut mekanisme koordinasi yang terutama berlaku. Walaupun dapat menggunakan model yang abstrak, sistem perekonomian yang berisi satu dari tiga mekanisme sosial. Sistem perekonomian masa sekarang yang sebenarnya mempunyai ketiganya dalam berbagai perbandingan. Tetapi, biasanya hanya salah satu mekanisme sosial yang dominan.

Sistem ekonomi yang dipakai suatu bangsa atau masyarakat akan sangat mempengaruhi kemakmuran dan kehidupan bangsa atau masyarakat itu sendiri. Karenanya, dapat dinyatakan bahwa dasar filosofis antara ekonomi kapitalis dan ekonomi Islâm sangat jauh berbeda. Hal ini dapat dilihat di mana ekonomi kapitalis lebih menekankan personal liberty, private property dan, private enterprise. Sedangkan dalam Islâm lebih berorientasi pada tawâzun dan ta'âwun, dalam arti bahwa kerjasama (cooperation) merupakan karakter dari ekonomi Islâm. Baik ekonomi kapitalis maupun ekonomi Islâm, keduanya merupakan faham yang netral tidak memihak terhadap kekuatan politik tertentu.

\section{Daftar Pustaka:}

Ali, Muhammad Daud. Sistem Ekonomi Islam: Zakat dan Wakaf. Jakarta: UI Press, 1988 
Beger, Peter L. "Kapitalisme Suatu Fenomena" dalam Arus Pemikiran Ekonomi Politik: Esei-Esei Terpilih, ed. Amir Effendi. Yogyakarta: Tiara Wacana, 1999.

Chapra, Umer, Islam and The Economic Challenge. Terj. Nurhadi Ihsan dan Rifqi Amar. Surabaya: Risalah Gusti, 1999.

Damanhuri, Didin S. Pilar-Pilar Reformasi Ekonomi Politik: Upaya Memahami Krisis Ekonomi dan Menyongsong Indonesia Baru. Jakarta: CIDES, 1999.

Fakih, Mansour. Sesat Pikir Teori Pembangunan dan Globalisasi. Yogyakarta: Insist Press dan Pustaka Pelajar, 2001.

Fathonah Business Consulting (FBC), Sistem Ekonomi Islam. Makalah disajikan dalam Seminar dan Lokakarya Membangun Ekonomi Syariah di Madura, Lembaga Pengkajian dan Penerapan Syariat Islam (LP2SI) Kabupaten Pamekasan (Pamekasan: 7 Januari 2008)

Galner, Ernest. Post Modernism Religion. London: Rroutledge, 1992.

Grossman, Gregory. Sistem-sistem Ekonomi, terj. Anas Sidik. Jakarta: Bumi Aksara, 2001

Karim, Adiwarman Azwar. Sejarah Pemikiran Ekonomi Islam. Jakarta: Raja Grafindo Persada, 2006

--------. Ekonomi Mikro Islami. Jakarta: Raja Grafindo Persada, 2007

Mannan, M. Abdul. Teori dan Praktek Ekonomi Islam, terj. M. Nastangin. Yogyakarta: Dana Bhakti Prima Yasa, 1997.

Nursalim. Ekonomi Islam Sistem Ekonomi Alternatif, Makalah disajikan dalam dalam Seminar Ilmiah Keislaman FE Unair Surabaya, (Surabaya, 20 Mei 1995). 
Perkasa, Beta. "IMF, Bank Dunia dan Evolusi Kapitalisme". Jurnal Pangsa-FE UGM, edisi 6, VI, (Mei 2001).

Rodinson, Maxime. Islam dan Kapitalisme. Terj. Asep Hikmat. Bandung: IQRA, 1982.

Saifuddin, A.M. "Filsafat, Nilai Dasar, Nilai Instrumental, dan Fungsionalisasi Konsep Ekonomi Islam". dalam Solusi Islam Atas Berbagai Persoalan Umat. Ed. Tim GIP. Jakarta: Gema Insani Press, 1998.

Sanusi, Bachrawi. Tokoh Pemikir dalam Mazhab Ekonomi. Jakarta: Rineka Cipta, 2004.

Sawit, M. Husein. "Sistem Ekonomi Islam" dalam Metodologi Ilmu Ekonomi Islam: Suatu Pengantar. Ed. Gunawan Muhammad. Yogyakarta: UII Press, 1999.

Soros, George. The Crisis of Global Capitalism (Open Society Endangered). Terj. Dindin Solahudin. Yogyakarta: Al-Qalam, 2001.

Supriadi, Eko. Sosialisme Islam: Pemikiran Ali Syari'at. Yogyakarta: Pustaka Pelajar, 2003.

Sutrisno. Welfare State dan Welfare Society dalam Ekonomi Pancasila. Yogyakarta: FE-UGM, 1982.

Swasono, Sri Edi. Pandangan Islam dalam Sistem Ekonomi Indonesia. Jakarta: UI Press, 1987. 